\title{
DIGESTA FLOWS IN SHEEP FED POOR-QUALITY HAY SUPPLEMENTED WITH UREA AND CARBOHYDRATES
}

\author{
I. Ortigues ${ }^{1,2,3}$ J. P. Fontenot ${ }^{1}$ and J. G. Ferry ${ }^{4}$ \\ Virginia Polytechnic Institute and State University 5 \\ Blacksburg 24061
}

\begin{abstract}
Two metabolism trials were conducted with 12 yearling crossbred wethers per trial ( 34 and $38 \mathrm{~kg}$ for trials 1 and 2 , respectively). The wethers, equipped with ruminal, abomasal and ileal cannulae, were randomly allotted for each trial to the following treatments: 1) hay alone or hay supplemented with 2) $.9 \%$ urea, 3) $1 \%$ urea and $6.5 \%$ molasses or 4 ) $1 \%$ urea and $5.2 \%$ corn. Two digestive flow markers were used: $\mathrm{Cr}_{2} \mathrm{O}_{3}$ powder and Co-ethylenediaminetetraacetic acid (CoEDTA). Urea and Co-EDTA were infused continuously into the rumen via cannula. Daily dry matter (DM) intake averaged $517 \mathrm{~g}$. Urea supplementation improved $\mathrm{N}$ retention $(P<.01)$. Apparent digestibility of DM, acid detergent fiber (ADF) and energy was not affected by treatment. Urea and carbohydrate supplementation increased ruminal propionic acid molar proportions $(P<.05)$. Apparent ruminal DM digestion accounted for $41 \%$ of the total DM degraded, whereas $77.4 \%$ of the digestible ADF was degraded in the rumen. Urea supplementation increased ADF digestion in the large intestine $(P<.01)$. Urea and carbohydrate supplementation resulted in a stepwise increase in $\mathbf{N}$ flowing with the liquid phase at the abomasum. Mean retention times of the solid and liquid phases of digestive contents were similar across treatments. Overall, benefits of supplementation of poor-quality fescue hay diets by small amounts of urea and readily available carbohydrates remain questionable for sheep fed at a fixed level of intake below maintenance.

(Key Words: Urea, Molasses, Maize, Ruminants, Sheep, Festuca.)
\end{abstract}

\section{Introduction}

Large improvements have been accomplished in forage production and conservation; however, large quantities of poor-quality forages are still produced. Intake of such forages is generally limited, and $\mathrm{N}$ supplementation is essential for optimal intake (Church and Fontenot, 1979). Urea, a relatively inexpensive source of $\mathrm{N}$, is widely used, but responses to urea have been variable, without any apparent explanations (Johnson, 1976).

When a low- $\mathrm{N}$ basal diet is supplemented with urea, a source of carbohydrate is required (Mills et al., 1944). It is generally believed that urea-molasses supplements are beneficial in grazing management. In a grazing trial with

\footnotetext{
${ }^{1}$ Dept. of Anim. Sci.

${ }^{2}$ Supported by John Lee Pratt Fellowship.

${ }^{3}$ Present address: Institut National de Recherche Agronomique, 63122 Ceyrat, France.

${ }^{4}$ Dept. of Anaerobic Microbiol.

${ }^{5}$ Appreciation is expressed to Dr. S. Rahnema for his guidance in surgery.

Received April 3, 1987.

Accepted August 26, 1987.
}

sheep, Nolan et al. (1975) calculated that a urea-molasses supplement was used as an energy source, and in no instance did it prevent the sheep from losing weight. In another trial with sheep fed oat straw and urea, the addition of starch increased feed intake, weight gain and wool production, but at least $10 \%$ starch was required for a net gain in tissue energy storage (Mulholland et al., 1976). Corn was shown to improve $\mathrm{N}$ retention to a greater extent than cane molasses, when fed at more than $40 \%$ of the diet (Bell et al., 1953).

The objectives of this study were to determine the effects of urea on the use of poorquality hay by sheep and to compare the further supplementation of sugarcane molasses or corn grain. Nitrogen and energy supplements were fed at levels equivalent to the level of intake of urea-molasses liquid supplement when self-fed in a lick tank (Ortigues et al., 1982).

\section{Experimental Procedure}

Animals. Two metabolism trials were conducted with 12 yearling crossbred (Western $x$ Suffolk) wethers (avg weight, $35.9 \mathrm{~kg}$ ) in each 
TABLE 1. COMPOSITION OF THE DIETS ${ }^{a}$

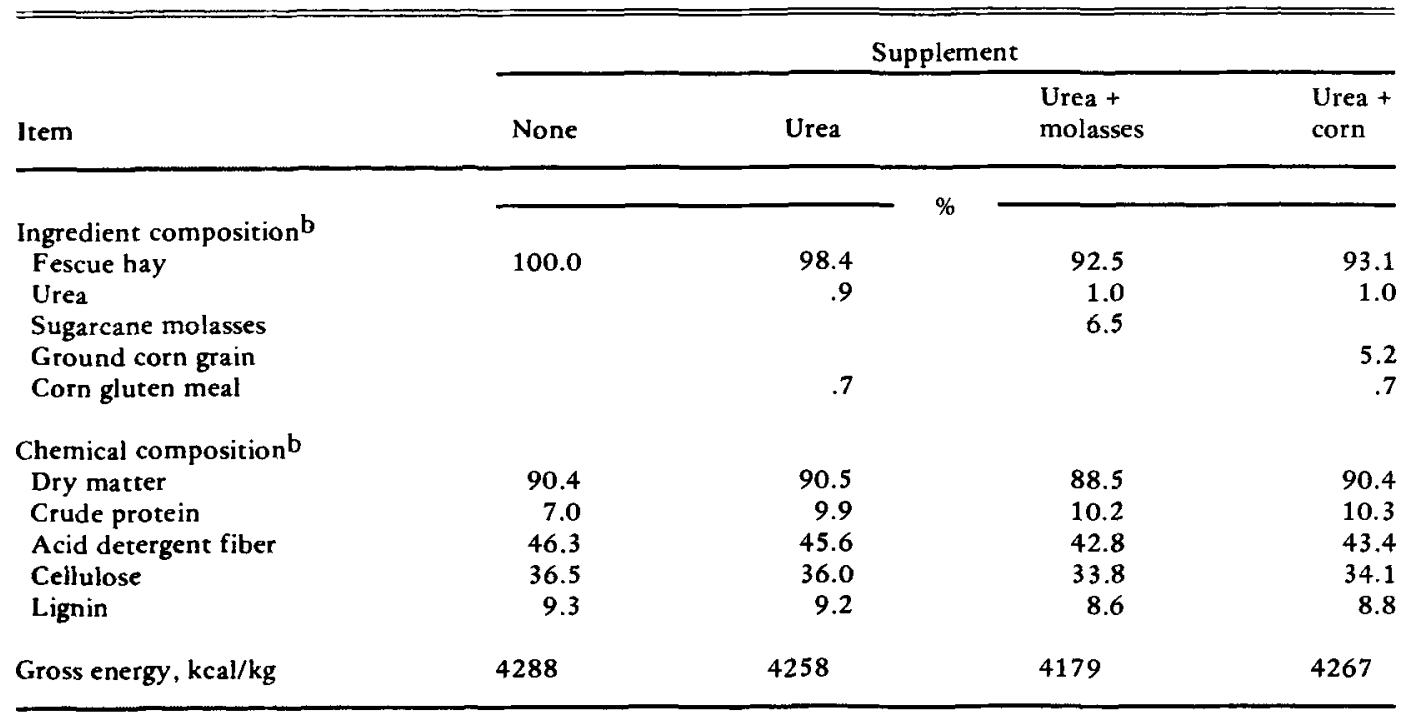

\footnotetext{
${ }^{a}$ Mineral supplement consisting of $10 \mathrm{~g}$ of trace mineral salt and $10 \mathrm{~g}$ of defluorinated phosphate was fed daily to each wether.

${ }^{b}$ Dry-matter basis.
}

trial. The wethers were equipped with abomasal, ileal and ruminal cannulae. The wethers were fitted, 2 mo before the trials, with a single plexiglass-polyethylene cannula ${ }^{6}$ at the abomasum (10 $\mathrm{cm}$ from the pyloric valve, and exteriorized behind the last rib) and a $T$-shaped stainless-steel cannula ${ }^{6}$ at the distal ileum (10 to $15 \mathrm{~cm}$ from the ileo-cecal juncture, and exteriorized higher up on the right flank). A single ruminal cannula made from Tygon tubing (id $1.25 \mathrm{~cm}$ ) and glued together with cyclohexanone was subsequently implanted nonsurgically according to a modification of the procedure described by Faichney and Colebrook (1979) for ruminal catheters. No difficulties were experienced with the abomasal and ileal cannulae, whereas ruminal cannulae allowed leakage of ruminal fluid on most wethers after 6 mo.

Wethers were blocked by weight and randomly allotted to the treatment groups for each trial with the restriction that no animal would receive the same treatment during the two trials. Wethers were kept in metabolism crates allowing separate collection of feces and urine (Briggs and Gallup, 1949).

\footnotetext{
${ }^{6}$ Precision Machine Co., Lincoln, NE.

${ }^{7}$ Mandostat, New York.
}

Diets. Four treatment diets were compared (Table 1). The basal diet consisted of chopped, poor-quality fescue-clipping hay. The supplements used were urea, sugarcane molasses, ground corn grain and corn gluten meal. Amounts of dry matter (DM) consumed were equalized across treatments on the basis of $90 \%$ ad libitum intake achieved by wethers on the basal diet.

The diets were fed in two equal portions at 12-h intervals. Urea was infused continuously into the rumen via cannulae, using multichannel cassette infusion pumps ${ }^{7}$; a sham infusion of water was administered to the control group. Chromic oxide powder ( $2 \mathrm{~g} / \mathrm{d}$ or $1 \mathrm{~g} /$ feeding) was introduced into the rumen at mealtime, and Co-EDTA $(2 \mathrm{~g} / \mathrm{d})$ was infused continuously into the rumen with the urea or sham infusates. At the end of the sampling period, the daily administration of markers was stopped and single larger doses of $\mathrm{Cr}_{2} \mathrm{O}_{3}(6 \mathrm{~g})$ and $\mathrm{Co}-\mathrm{EDTA}$ $(6 \mathrm{~g})$ were administered at feeding time to measure mean retention time.

Experimental Plan. Each trial consisted of a 6-d transition period, a 10-d preliminary period and a 7-d collection of feed, feces and urine. This was followed by a 6-d sampling of feed, feces, blood, ruminal fluid and gas, abomasal and ileal contents and a 5-d total collection of feces every $4 \mathrm{~h}$. Fecal material was collected 
daily, dried in a forced-air oven at a maximum of $50 \mathrm{C}$ and composited. Urine was collected in $15 \mathrm{ml}$ of $50 \% \mathrm{H}_{2} \mathrm{SO}_{4}(\mathrm{v} / \mathrm{v})$, subsampled and cornposited. Samples were taken of blood (via jugular puncture), of ruminal fluid (from the ventral sac, via cannula) and of ruminal gas (through cannula, using a device similar to that described by Sumio et al. [1983]) once daily, advancing the time by $4 \mathrm{~h}$ each day to represent every $4 \mathrm{~h}$ of the clock. The ruminal gas samples were stored in vacutainers previously filled with $N_{2}$. Abomasal and ileal contents were sampled manually at 12 -h intervals daily, advancing the time by $2 \mathrm{~h}$ each day to represent every $2 \mathrm{~h}$ of the clock. They were then composited on an equal-volume basis. Samples of digestive contents were then centrifuged at $2,000 \times g$ for $10 \mathrm{~min}$. Liquid phase, obtained by pouring off all the supernatant, was frozen at $-20 \mathrm{C}$ until further analyses. The residues, considered as representing the solid phase, were freeze-dried and ground through a $.5-\mathrm{mm}$ screen.

Chemical Analyses. Ammonia was determined according to the Conway (1958) proceclure, chromic oxide according to Hill and Anderson (1958), and cobalt by atomic absorption $^{8}$ after a nitric-perchloric acid digestion. Energy was determined with an adiabatic boinb calorimeter ${ }^{9}$, and methane and carbon dioxide by procedures described by Schauer and Ferry (1980).

In samples of the collection period, $\mathrm{N}$ was analyzed by the Kjeldahl procedure (AOAC, 19.30); $\mathrm{N}$ was analyzed for the sampling period by Nesslerization (Umbreit et al., 1957). Nonprotein- $\mathrm{N}$ was separated from protein- $\mathrm{N}$ by trichloroacetic acid precipitation. The method of Coulombe and Favreau (1963) was used to determine urea. Acid detergent fiber (ADF) and lignin were analyzed according to Goering and Van Soest (1970). Volatile fatty acids (VFA) were measured by gas chromatography by procedures described by Panditharatne et al. (1986).

Calculations. Fecal excretion during the sampling period was calculated from the $\mathrm{Cr}_{2} \mathrm{O}_{3}$ concentrations in feces corrected for $100 \%$ fecal recovery. The flow rates of liquid and solid phases were calculated according to Armentano and Russell (1985), assuming the wethers were in a steady state over a 24-h

\footnotetext{
${ }^{8}$ Spectrophotometer 403, Perkin Elmer Corp., Norwalk, CT.

${ }^{9}$ Parr Instrument Co., Moline, IL.
}

period. In these conditions, the instantaneous rate of change in the amount of marker over time at the point of sampling is equal to zero; it is also equal to the difference between the quantity of marker arriving at the point of sampling and that leaving. The equations were as follows:

$$
\mathrm{AR}_{1}=\mathrm{F}_{S}\left[\mathrm{Cr}_{2} \mathrm{O}_{3}\right]_{S}+\mathrm{F}_{L}\left[\mathrm{Cr}_{2} \mathrm{O}_{3}\right]_{L}
$$

and

$$
\mathrm{AR}_{2}=\mathrm{F}_{S}[\mathrm{Co}]_{S}+\mathrm{F}_{L}[\mathrm{Co}]_{L}
$$

therefore,

$$
\mathrm{F}_{L}=\frac{\left(\mathrm{AR}_{1} \cdot[\mathrm{Co}]_{S}-\mathrm{AR}_{2} \cdot\left[\mathrm{Cr}_{2} \mathrm{O}_{3}\right]_{S}\right)}{\left([\mathrm{Co}]_{S} \cdot\left[\mathrm{Cr}_{2} \mathrm{O}_{3}\right]_{L}-[\mathrm{Co}]_{L} \cdot\left[\mathrm{Cr}_{2} \mathrm{O}_{3}\right]_{S}\right)}
$$

and

$$
\mathrm{F}_{S}=\frac{\left(\mathrm{AR}_{2}-\mathrm{F}_{L} \cdot[\mathrm{Co}]_{L}\right)}{[\mathrm{Co}]_{S}}
$$

The terms $\mathrm{AR}_{1}$ and $\mathrm{AR}_{2}$ are the rates $(\mu \mathrm{g}$ marker/min) of continuous administration of $\mathrm{Cr}_{2} \mathrm{O}_{3}$ and $\mathrm{Co}$, respectively; $\mathrm{F}_{S}$ and $\mathrm{F}_{L}$ refer to flow ( $\mathrm{g}$ digesta phase/min) of the solid and liquid phases, respectively; $\left[\mathrm{Cr}_{2} \mathrm{O}_{3}\right]_{S}$ and $\left[\mathrm{Cr}_{2} \mathrm{O}_{3}\right]_{L}$ refer to concentrations of $\mathrm{Cr}_{2} \mathrm{O}_{3}$ in the solid and liquid phases, respectively; and $[\mathrm{Co}]_{S}$ and $[\mathrm{Co}]_{L}$ refer to concentration of Co in the solid and liquid phases, respectively ( $\mu \mathrm{g}$ marker/g digesta phase).

Marker concentrations in abomasal and ileal solid and liquid phases were adjusted based on the difference in total fecal recovery of $\mathrm{Cr}$ and Co from $100 \%$. The flow rate of any constituent was assumed to be equal to the sum of the flow rates of that constituent in the solid and liquid phases as follows: flow of nutrient $=$ $\mathrm{F}_{L}$ (nutrient) $)_{L}+\mathrm{F}_{S}$ (nutrient) $S$. The mean retention time was calculated as described by Faichney (1975).

Statistical Analyses. The ruminal and blood variables were analyzed according to a splitplot design with time trend, block effect nested within trial as the split-plot factor. The model included trial, treatment, block (within trial), time, trial $x$ treatment, treatment $x$ time and treatment $x$ block. Balance trial and the flow data were analyzed according to the following model: trial, block (within trial), treatment and trial $x$ treatment. In both models the error 
mean square was that for trial $x$ treatment $x$ block interaction. Because of missing observations for two sheep caused by large feed refusals, the data were analyzed by SAS (1982), using the least-squares procedure described by Harvey (1975). Treatment means were compared by orthogonal contrasts. Contrasts were supplemented vs. unsupplemented, urea vs urea plus carbohydrate supplementation, and molasses vs corn supplementation. Time effect was tested by orthogonal polynomials.

\section{Results}

Dry Matter Intake. The main feature of these data is that the level of intake was generally very low as determined from the ad libitum intake of wethers on the basal diet. It was observed, however, that wethers receiving the urea supplemented diets would have increased their intake, relative to the control group, if allowed to. Dry matter intake was $10 \%$ higher in the second than in the first trial, probably due to elevated $D M$ and $\mathrm{N}$ contents of the hay (1.04 and $1.21 \% \mathrm{~N}$, dry basis, in the first and second trials, respectively). This difference in intake was responsible for the trial or trial $x$ treatment effects noted for some variables. Treatment differences were greater in the first than in the second trial, hence the interaction term. In both trials, however, effects were in the same direction, which explains the presentation of the average results only. Differences in urea feeding across diets (Table 1) resulted from variations in the volumes of urea solution effectively infused.

Weight Changes. At the beginning of trials 1 and 2 , wethers weighed $33.5 \mathrm{~kg}$ and $38.3 \mathrm{~kg}$, respectively. They lost an average of $2.8 \mathrm{~kg}$ and $6.4 \mathrm{~kg}$ during the respective trials. For the two trials, weight losses averaged 4.01, 4.23, 5.29 and $4.95 \mathrm{~kg}$ for the wethers fed the control diet and diets supplemented with urea, molasses and corn, respectively.

Marker Recovery. Based on total fecal collection, recovery of $\mathrm{Cr}_{2} \mathrm{O}_{3}$ and $\mathrm{Co}$ averaged $98.47 \pm 1.47 \%$ and $106.78 \pm 1.76 \%$, respectively. Urinary recovery of Co was $3.83 \pm .24 \%$.

Balance Trial. Apparent digestibility of DM and ADF was low and was not affected by treatments (Table 2). Apparent $\mathrm{N}$ digestibility for the total diet was improved by urea supplementation $(P<.01)$. If urea digestibility is assumed to be $100 \%$, then supplements did not

TABLE 2. APPARENT DIGESTIBILITY OF DRY MATTER, ACID DETERGENT FIBER, NITROGEN AND ENERGY, AND NITROGEN BALANCEa

\begin{tabular}{|c|c|c|c|c|c|}
\hline \multirow[b]{2}{*}{ Item } & \multicolumn{4}{|c|}{ Supplement } & \multirow[b]{2}{*}{$S^{b}$} \\
\hline & None & Urea & $\begin{array}{l}\text { Urea }+ \\
\text { molasses }\end{array}$ & $\begin{array}{l}\text { Urea + } \\
\text { corn }\end{array}$ & \\
\hline Dry matter intake, $g / d^{c}$ & 517 & 519 & 509 & 523 & 1.3 \\
\hline \multicolumn{6}{|l|}{ Apparent digestibility, $\% \mathfrak{c}$} \\
\hline Dry matter & 44.9 & 45.1 & 47.5 & 46.9 & .45 \\
\hline Acid detergent fiber & 44.0 & 44.2 & 44.7 & 43.1 & .58 \\
\hline Crude protein de & 25.2 & 51.1 & 51.4 & 53.3 & .93 \\
\hline Energye & 43.6 & 45.0 & 46.8 & 46.0 & .62 \\
\hline \multicolumn{6}{|l|}{ Nitrogen balance, $g / d$} \\
\hline Intake cd & 5.8 & 9.0 & 9.0 & 9.5 & .09 \\
\hline Fecalc & 4.3 & 4.4 & 4.4 & 4.4 & .05 \\
\hline Urinary cd & 3.8 & 5.0 & 5.6 & 5.2 & .20 \\
\hline Retention ${ }^{d}$ & -2.3 & -.4 & -.9 & -.1 & .23 \\
\hline
\end{tabular}

\footnotetext{
${ }^{\text {a }}$ Least-squares means.

${ }^{\mathrm{b}}$ Standard error of the mean.

$c_{\text {Trial effect }}(P<.05)$.

${ }^{d}$ Values for the hay diet are different from values for the urea, molasses and corn supplemented diets $(P<.01)$.

$\mathrm{e}_{\text {Trial }} \times$ treatment interaction $(P<.05)$.
} 
TABLE 3. RUMINAL AND BLOOD MEASUREMENTS OF WETHERS FED POOR-QUALITY HAY ${ }^{a}$

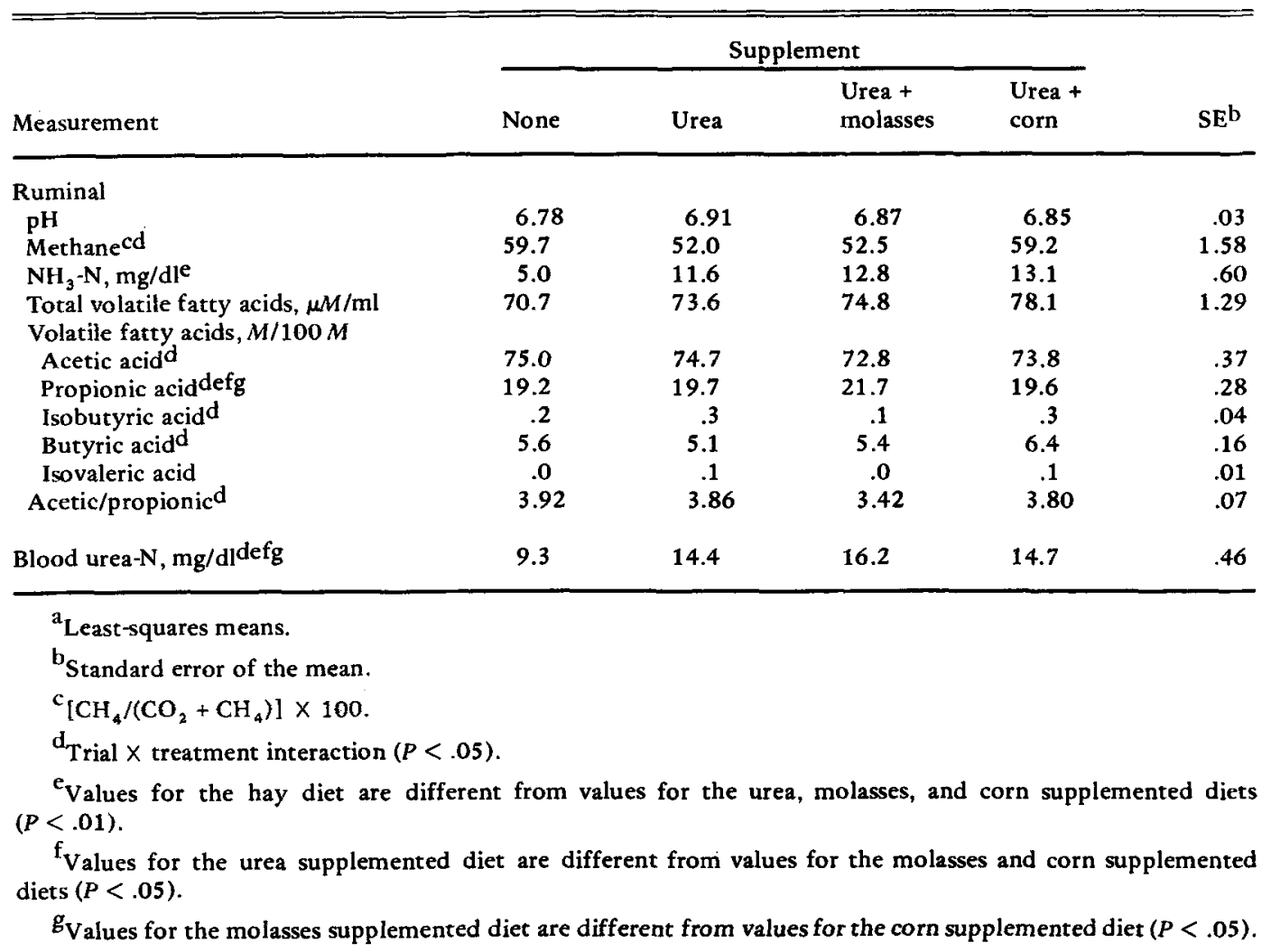

affect $\mathrm{N}$ digestibility of the hay. Nitrogen balance was negative for all treatments, but urea addition improved $\mathrm{N}$ retentios $(P<.01)$.

Ruminal and Blood Parameters. No treatment $x$ time interaction was observed for any of the parameters measured, indicating that the kinetics of ruminal digestion were not altered by urea or carbohydrate supplementation. Ruminal $\mathrm{pH}$ was similar among treatments and was relatively stable after feeding (Table 3 ). Ruminal $\mathrm{NH}_{3}-\mathrm{N}$ and blood urea- $\mathrm{N}$ concentrations were not affected by treatments. Concentrations in these variables decreased for 6 to $10 \mathrm{~h}$ after feeding and increased thereafter $(P<.01)$. Total VFA varied between 70.7 and $78 \mu \mathrm{M} / \mathrm{ml}$ (Table 3). Urea and carbohydrate supplementation resulted in statistically significant stepwise increases in molar proportions of propionic acid. Branched-chain VFA were not found at all times nor in all wethers, and valeric acid was never detected. Concentrations of total VFA (Figure 1) and acetic, propionic and butyric acids decreased linearly with time after feeding $(P<.01)$. There was a tendency, how- ever, for this decrease to start only $6 \mathrm{~h}$ after feeding, the time ruminal $\mathrm{pH}$ tended to be lowest. Proportions of methane in the rumen gas were high (Table 3 ) and increased linearly $(P<.01)$ with the time after feeding (Figure 2$)$. Methane proportion tended to be higher for

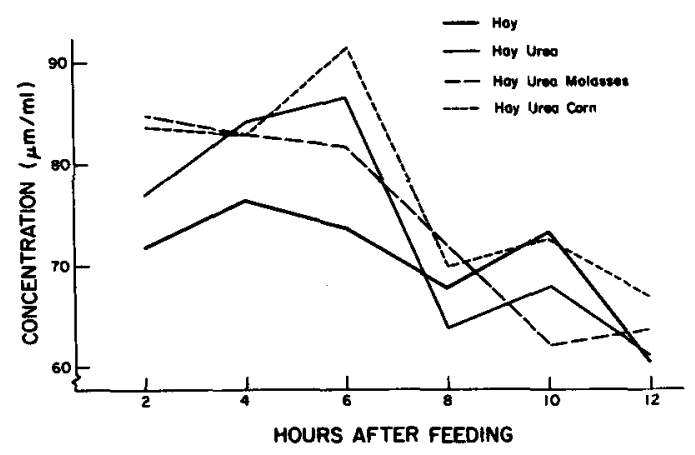

Figure 1. Postprandial changes in ruminal concentrations of total volatile fatty acids in wethers. Standard error for treatment $X$ time interaction is 4.01 . 


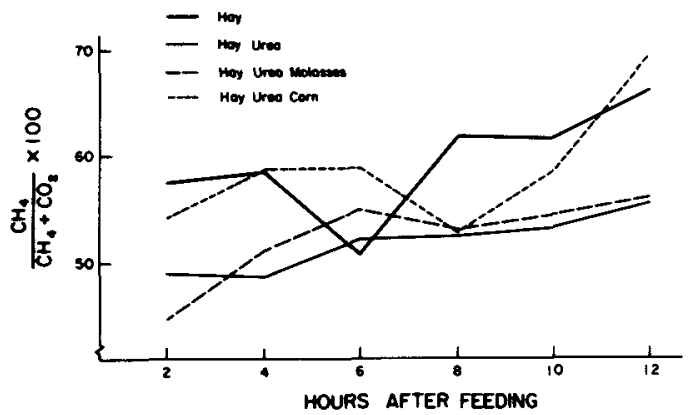

Figure 2. Postprandial changes in proportion of methane in ruminal gas in wethers. Standard error for treatment $X$ time interaction is 3.07 .

the control and corn supplemented diets, but differences were not significant.

Sites of Dry Matter and Acid Detergent Fiber Digestion. As calculated by difference between the measured fecal DM output of the collection and sampling periods, sampling removed an average of $12 \%$ of the DM of the digestible contents.

Dry matter flows along the gastro-intestinal tract were similar across treatments (Table 4). Dry matter flowing with the liquid phase represented $15 \%$ and $14 \%$ of the total DM flow at the abomasum and ileum, respectively. The apparent DM digestion in the intestines was quite important, compared with pre-intestine digestion. In fact, $41 \%, 36 \%$ and $23 \%$ of the apparently digestible DM was digested in the stomach, small intestine and large intestine, respectively. Flows of ADF were based solely on the solid phase (Table 5). The stomach compartments were the primary sites of ADF digestion, accounting for the degradation of $77 \%$ of the digestible ADF. Urea supplementation in-

TABLE 4. DRY MATTER FLOW AND DIGESTION IN WETHERS FED POOR-QUALITY HAYa

\begin{tabular}{|c|c|c|c|c|c|}
\hline \multirow[b]{2}{*}{ Item } & \multicolumn{4}{|c|}{ Supplement } & \multirow[b]{2}{*}{$\mathbf{S E}^{\mathrm{b}}$} \\
\hline & None & Urea & $\begin{array}{l}\text { Urea + } \\
\text { molasses }\end{array}$ & $\begin{array}{l}\text { Urea + } \\
\text { corn }\end{array}$ & \\
\hline Intake, $g / d^{c d e f}$ & 523 & 521 & 509 & 519 & .9 \\
\hline \multicolumn{6}{|l|}{ Flow, g/d } \\
\hline Solid phase & 352 & 362 & 331 & 357 & 7 \\
\hline Liquid phasec & 59 & 62 & 63 & 70 & 4 \\
\hline \multicolumn{6}{|l|}{ lleum } \\
\hline Solid phase & 273 & 284 & 277 & 284 & 6 \\
\hline Liquid phasec & 40 & 43 & 42 & 50 & 2 \\
\hline Feces & 283 & 260 & 261 & 266 & 4 \\
\hline \multicolumn{6}{|l|}{ Digested } \\
\hline \multicolumn{6}{|l|}{ Pre-intestinally } \\
\hline $\mathrm{g} / \mathrm{d}$ & 113 & 98 & 115 & 92 & 7 \\
\hline$\%$ of intake & 21.3 & 18.9 & 22.5 & 17.6 & 1.3 \\
\hline \multicolumn{6}{|l|}{ Small intestine } \\
\hline $\mathrm{g} / \mathrm{d}$ & 97 & 96 & 75 & 94 & 6 \\
\hline$\%$ of intake & 18.6 & 18.4 & 14.7 & 18.2 & 1.1 \\
\hline \multicolumn{6}{|l|}{ Large intestine } \\
\hline$g / d^{c}$ & 35 & 67 & 57 & 70 & 5.2 \\
\hline$\%$ of intake ${ }^{c}$ & 6.6 & 12.7 & 11.1 & 13.3 & 1.0 \\
\hline
\end{tabular}

\footnotetext{
${ }^{a}$ Least-squares means.

b Standard error of the mean.

Trial effect $(P<.05)$.

${ }^{d}$ Values for the hay diet are different from values for the urea, molasses, and corn supplemented diets

${ }^{\mathrm{e}}$ Values for the urea supplemented diet are different from values for the molasses and corn supplemented diets $(P<.01)$.

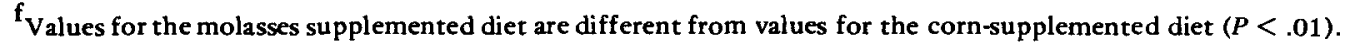
$(P<.01)$. 
TABLE 5. ACID DETERGENT FIBER FLOW AND DIGESTION IN WETHERS FED POOR-QUALITY HAYa

\begin{tabular}{|c|c|c|c|c|c|}
\hline \multirow[b]{2}{*}{ Item } & \multicolumn{4}{|c|}{ Supplement } & \multirow[b]{2}{*}{$S^{b}$} \\
\hline & None & Urea & $\begin{array}{l}\text { Urea + } \\
\text { molasses }\end{array}$ & $\begin{array}{l}\text { Urea }+ \\
\text { corn }\end{array}$ & \\
\hline Intake, $g / d^{c d e f}$ & 249 & 245 & 225 & 230 & .6 \\
\hline \multicolumn{6}{|l|}{ Flow, g/d } \\
\hline Abomasum & 149 & 152 & 137 & 148 & 4 \\
\hline Ileum & 122 & 132 & 126 & 130 & 3 \\
\hline Feces & 128 & 117 & 115 & 122 & 2 \\
\hline \multicolumn{6}{|l|}{ Digested } \\
\hline \multicolumn{6}{|l|}{ Pre-intestinally } \\
\hline $\mathrm{g} / \mathrm{d}$ & 100 & 92 & 87 & 82 & 4 \\
\hline$\%$ of intake & 40.1 & 37.8 & 38.9 & 35.6 & 1.6 \\
\hline \multicolumn{6}{|l|}{ Small intestine } \\
\hline $\mathrm{g} / \mathrm{d}$ & 27 & 21 & 11 & 18 & 3 \\
\hline$\%$ of intake & 10.8 & 8.4 & 5.1 & 8.2 & 1.4 \\
\hline \multicolumn{6}{|l|}{ Large intestine } \\
\hline$g / d^{d}$ & -4 & 14 & 11 & 9 & 2.0 \\
\hline$\%$ of intaked & -1.7 & 5.8 & 4.8 & 3.7 & .8 \\
\hline
\end{tabular}

${ }^{a}$ Least-squares means.

${ }^{b}$ Standard error of the mean.

Crial effect $(P<.01)$.

${ }^{d}$ Values for the hay diet are different from values for the urea, molasses, and corn supplemented diets $(P<.01)$.

${ }^{e}$ Values for the urea supplemented diet are different from values for the molasses and corn supplemented $\operatorname{diets}(P<.01)$.

${ }^{f}$ Values for the molasses supplemented diet are different from values for the corn supplemented $\operatorname{diet}(P<.01)$.

creased $(P<.01)$ ADF digestion in the large intestine.

Sites of Nitrogen Digestion. Total $\mathrm{N}$ flow at the abomasum represented $173 \%, 108 \%, 116 \%$ and $128 \%$ of $\mathrm{N}$ intake for the control, urea, urea-molasses and urea-corn supplemented diets, respectively (Table 6). Digestion of $\mathrm{N}$ in the intestines was not different $(P>.05)$ among treatments, but the extent of $\mathrm{N}$ digestion in the small intestine tended to be greater for the control diet and the diet containing the urea-corn supplement.

Mean Retention Time. The mean retention time ( \pm standard error) of $\mathrm{Cr}_{2} \mathrm{O}_{3}$ in the entire gastro-intestinal tract was $39 \pm 1.5,41 \pm 1.25$, $38.5 \pm 1.5$ and $38.0 \pm 1.5 \mathrm{~h}$ for the control and for diets supplemented with urea, with urea plus molasses and with urea plus corn, respectively. The mean retention time of cobalt was $32.0 \pm 2.0,33.2 \pm 1.8,31.0 \pm 2.0$ and $29.5 \pm$ $2.0 \mathrm{~h}$, respectively. No significant differences among treatments were observed.

\section{Discussion}

The low intake of poorly digestible forage by cannulated, growing wethers made the wethers more susceptible to stress. Indeed, wethers in the present study consumed only $29 \%$ of the NRC (1985) recommendations for digestible energy of $35 \mathrm{~kg}$ wethers growing at $285 \mathrm{~g} / \mathrm{d}$ and $19 \%$ to $32 \%$ of the recommended crude protein levels. These intake figures do not account for the removal of digesta by sampling. The problems relating to the use of poorquality forages by ruminants are therefore linked to some extent with those problems of feeding animals below maintenance, and illustrate some of the difficulties that can be encountered in such studies.

Lignification of the hay was high, which impeded ruminal degradation. Consequently, the level of digestible energy intake was too low to permit large benefits from urea. Adding small amounts of carbohydrates was of no ap- 
TABLE 6. NITROGEN FLOW AND DIGESTION IN WETHERS FED POOR-QUALITY HAY ${ }^{a}$

\begin{tabular}{|c|c|c|c|c|c|}
\hline \multirow[b]{2}{*}{ Item } & \multicolumn{4}{|c|}{ Supplement } & \multirow[b]{2}{*}{$\mathrm{SE}^{\mathrm{b}}$} \\
\hline & None & Urea & $\begin{array}{l}\text { Urea }+ \\
\text { molasses }\end{array}$ & $\begin{array}{l}\text { Urea }+ \\
\text { corn }\end{array}$ & \\
\hline Intake, $g / d^{\text {cde }}$ & 5.89 & 8.66 & 8.38 & 8.93 & .05 \\
\hline \multicolumn{6}{|l|}{$\begin{array}{l}\text { Flow, } \mathrm{g} / \mathrm{d} \\
\text { Abomasum }\end{array}$} \\
\hline $\begin{array}{l}\text { Solid phase } \\
\text { Liquid phase }\end{array}$ & 8.74 & 7.59 & 7.38 & 9.56 & .28 \\
\hline Totalcdef & 1.47 & 1.80 & 2.37 & 1.91 & .06 \\
\hline Nonprotein-Ncd & 1.26 & 1.59 & 2.02 & 1.64 & .05 \\
\hline $\begin{array}{l}\text { lleum } \\
\text { Solid phase } \\
\text { Liquid phase }\end{array}$ & 3.96 & 3.80 & 4.38 & 3.50 & .17 \\
\hline $\begin{array}{l}\text { Liquid phase } \\
\text { Totalc }\end{array}$ & 1.30 & 1.56 & 1.62 & 1.76 & .11 \\
\hline Nonprotein $-\mathrm{N}^{\mathrm{C}}$ & .70 & .92 & .95 & 1.09 & .06 \\
\hline Feces & 3.97 & 3.72 & 3.95 & 3.85 & .07 \\
\hline Digested & & & & & \\
\hline $\begin{array}{l}\text { Pre-intestinal, g/dd } \\
\text { Small intestine }\end{array}$ & -4.32 & -.74 & -1.38 & -2.53 & .28 \\
\hline $\mathbf{g} / \mathbf{d}$ & 4.95 & 4.02 & 3.76 & 6.20 & .37 \\
\hline $\begin{array}{c}\% \text { of intake } \\
\text { Large intestine }\end{array}$ & 83.6 & 47.1 & 44.1 & 70.5 & 5.0 \\
\hline $\begin{array}{l}\text { Large intestine } \\
\mathbf{g} / \mathbf{d}\end{array}$ & 1.27 & 1.65 & 2.05 & 1.29 & .21 \\
\hline$\%$ of intake & 21.3 & 18.0 & 24.7 & 14.7 & 2.8 \\
\hline
\end{tabular}

${ }^{a}$ Least-squares means.

${ }^{b}$ Standard error of the mean.

$c_{\text {Trial effect }}(P<.01)$.

${ }^{d}$ Values for the hay diet are different from values for the urea, molasses, and corn supplemented diets $(P<.01)$.

eValues for the urea supplemented diet are different from values for the molasses and corn supplemented diets $(P<.05)$.

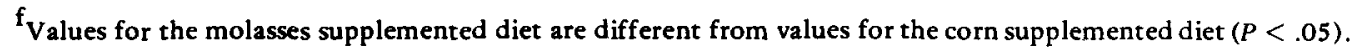

parent benefit. The poor nutritional status of the wethers and the additional stress due to removal of nutrients by sampling of digesta probably increased the variability of response among animals.

Nitrogen retention was improved by urea infusion $(P<.01)$ but not by carbohydrate addition. In a similar experiment with Pangola grass hay, Martin et al. (1981) obtained a significant stepwise increase in $\mathrm{N}$ retention with addition of urea and molasses. Those authors used slightly higher levels of molasses than were used in the present study. The enhanced $\mathrm{N}$ retention observed here with urea supplementation contradicts the trend for higher body weight losses observed with these treatments. It is not likely that differences in weight loss could be artifacts due to differences in gut fill, because DM digestibility and rates of passage of digesta along the tract were similar across treatments, whereas differences in DM intake were only slight.

Mean retention times were similar across treatments, although disturbances in digesta flow might have occurred as a result of sampling. Values of the mean retention time of the solid phase are similar to those quoted by Warner (1981) for whole digesta of sheep fed hay. Campling et al. (1962) noted that urea infusions increased rate of passage of food with ad libitum feed intake. With restricted intake, the increase in rate of passage was not so large, and Redman et al. (1980) did not detect any effect of urea supplementation.

It can be questioned whether the trend for 
additional weight loss of wethers fed the urea diets resulted from an energy requirement for excreting excess $N$ in the form of urea. Because the wethers were on a low-energy status, body reserves would be used, and it is known that $\mathrm{NH}_{3}$ detoxification is related to energy metabolism (Visek, 1972). Based on a hypothesis proposed by Krebs (1964), and assuming a ratio of muscle protein to water loss of 1 to 3 , it can be calculated that to excrete the excess $\mathrm{N}$, the required energy derived from muscle breakdown would account for $48 \%, 14 \%$ and $15 \%$ of the weight loss difference between the control diet and the urea, urea-molasses and urea-corn diets, respectively. These values are minimal estimates due to the uncertainties attached to calculating the energy cost of urea synthesis and excretion in the urine (Grisolia and Kennedy, 1966; Oldham and Lindsay, 1983).

Ruminal fermentations, as determined from $\mathrm{pH}$, VFA concentrations and molar proportions, and methane are characteristic of poorquality forage diets (Thomas and Rook, 1981) and showed only slight changes with supplementation. The linear changes of VFA concentrations with time point to slow ruminal degradation of hay not altered by urea supplementation, and are consistent with the suggestion that with such forages the ruminal microbial population is relatively stable (Barry et al., 1977; Thomas and Hodgson, 1979). The high acetate and methane proportions reveal the inefficient pattern of ruminal fermentations relative to the metabolism of end-products of digestion in ruminants (Thomas and Rook, 1981). Theoretical methane production was calculated using the stoichiometry of formation of fermentation end-products ( $\varnothing$ rskov et al., 1968) and yielded values of methane proportions 5 to 13 percentage units lower than those measured experimentally. The largest discrepancies were related to a higher variability of the results and could indeed be due to the sampling technique (Jouany and Senaud, 1979).

Apparent pre-intestinal DM digestion was less than DM digestion in the whole intestines. Because of the low intake and the low digestibility of the diets, the relative importance of endogenous plus microbial DM is magnified. Assuming that the DM of the abomasal liquid phase is mostly of microbial or endogenous origin (Hogan et al., 1969; Poncet, 1976) or is composed of solutes, all the remaining nondegraded dietary DM was recovered in the solid phase. In this case, the rumen accounted for the degradation of $67 \%$ of the total DM digestion. This figure is closer to the measured value of $77 \%$ of the $A D F$ digestion taking place in the rumen; to a large extent the difference probably was caused by the presence of microbes in the solid phase (Czerkawski, 1986).

No $\mathrm{S}$ was supplemented, so $\mathrm{N}$ to $\mathrm{S}$ ratios were 59 to 1,89 to 1,32 to 1 and 93 to 1 for the control, urea, urea-molasses and urea-corn supplemented diets, respectively. Bird (1972) showed that with S-deficient, urea-oat hulls diets, ruminal degradation of organic matter was limited, compared with $\mathrm{S}$ supplemented diets. It is not certain, however, that in the present study $\mathrm{S}$ was the primary limiting factor, especially because it was demonstrated with sheep that when the level of digestible energy was sufficient urea supplementation still enhanced microbial growth, even with $N$ to $S$ ratios of up to 60 to 1 (Elliott and Armstrong, 1982).

The marker, $\mathrm{Cr}_{2} \mathrm{O}_{3}$, is known to migrate independently of the solid phase (Corbett et al., 1960 ), and this may have been accentuated in the present study in which digestive contents were very fluid because of the forage diet and low intake. It was also noted that sampling removed a large portion of digestive contents. These factors contributed to the variability in the results and might explain the high DM and $\mathrm{ADF}$ digestion in the small intestine, which is contradictory with previous results (Ulyatt et al., 1975). Urea infusion increased $\mathrm{N}$ flow in the liquid phase at the abomasum, but the protein $\mathrm{N}$ values of the liquid phase were low, as expected from the small extent of ruminal fermentation.

It appears that growing wethers cannulated at three sites of the digestive tract are questionable models to study the use of poorquality forages. Cannulated wethers appear to be more susceptible to stress and to have a smaller capacity for intake than their intact pairs. Therefore, when the use of poor-quality forage diets by ruminants is studied with cannulated wethers, situations of net underfeeding can occur, as was the case in the present study, in which the techniques used were not precise enough to distinguish between the dietary, microbial and endogenous components of digesta. This study shows the need to separate the mechanisms of digestion of poorquality feeds and the effects of undernutrition experimentally. 
Urea improved $\mathrm{N}$ retention; however, it was fed in excessive quantities relative to the energy available, and therefore it was costly to excrete. Urea and carbohydrates were supplemented in proportions similar to those observed with ad libitum intake of hay and liquid supplement (Ortigues et al., 1982). The beneficial effects of low levels of readily available carbohydrates are still questionable.

\section{Literature Cited}

AOAC. 1980. Official Methods of Analysis (13th Ed.). Association of Official Analytical Chemists, Washington, DC.

Armentano, L. E. and R. W. Russell. 1985. Method for calculating digesta flow and apparent absorption of nutrients from non-representative samples of digesta. J. Dairy Sci. 68:3067.

Barry, T. N., A. Thompson and D. G. Armstrong. 1977. Rumen fermentation studies of two contrasting diets. 1. Some characteristics of the in vivo fermentation, with special reference to the composition of the gas phase, oxidation/reduction state and volatile fatty acid proportions. $J$. Agric. Sci, (Camb.) 89:183.

Bell, M. C., W. D. Gallup and C, K. Whitehair. 1953. Value of urea nitrogen in rations containing different carbohydrate feeds. J. Anim. Sci. 12:787.

Bird, P. R. 1972. Sulphur metabolism and excretion studies in ruminants. 9. Sulphur, nitrogen and energy utilization by sheep fed a sulphur-deficient and a sulphate supplemented, roughagebased diet. Aust. J. Biol. Sci. 25:1073.

Briggs, H. M. and W. D. Gallup. 1949. Metabolism stalls for wethers and steers. J. Anim. Sci. 8: 479.

Campling, R. C., M. Freer and C. C. Balch. 1962. Factors affecting the voluntary intake of food by cows. 3. The effect of urea on the voluntary intake of oat straw. Br. J. Nutr. 16:115.

Church, D. C. and J. P. Fontenot. 1979. Nitrogen metabolism and requirements. In: D. C. Church (Ed.) Digestive Physiology and Nutrition of Ruminants. Vol. 2. pp 25-55. O \& B Books, Corvallis, $O R$.

Conway, E. J. 1958. Microdiffusion Analysis and Volumetric Error (4th Ed.). McMillan Co., New York.

Corbett, J. L., J.F.D. Greenhalgh, I. McDonald and E. Florence. 1960. Excretion of chromium sesquioxide administered as a component of paper to sheep. Br. J. Nutr. 14:289.

Coulombe, J. J. and L. Favreau. 1963. A new simple semimicro method for colorimetric determination of urea. Clin. Chem. 9:102.

Czerkawski, J. W. 1986. Degradation of solid feeds in the rumen: Spatial distribution of microbial activity and its consequences. In: L. P. Milligan, W. L. Grovum and A. Dobson (Ed.) Control of Digestion and Metabolism in Ruminants. pp 158-172. Prentice-Hall, Englewood Cliffs, NJ.

Elliott, R. and D. G. Armstrong. 1982. The effect of urea and urea plus sodium sulphate on microbial protein production in the rumen of sheep given diets high in alkali-treated barley-straw. J. Agric. Sci. (Camb.) 99:51.

Faichney, G. J. 1975. The effect of formaldehyde treatment of a concentrate diet on the passage of solute and particulate markers through the gastro-intestinal tract of sheep. Aust. J. Agric. Res. 13:319.

Faichney, G. J. and W. F. Colebrook. 1979. A simple technique to establish a self-retaining rumen catheter suitable for long-term infusions. Res. Vet. Sci. 26:385.

Goering, H. K. and P. J. Van Soest. 1970. Forage Fiber Analyses: Apparatus, Reagents, Procedures and Some Applications. Handbook 379, ARS, USDA.

Grisolia, S. and J. Kennedy. 1966. On specific dynamic action, turnover and protein synthesis. Perspect. Biol. Med. 9:578.

Harvey, W. R. 1975. Least-squared analysis of data with unequal subclass numbers. USDA, ARS H-4, Beltsville, MD.

Hill, F. W. and D. L. Anderson. 1958. Comparison of metabolizable energy and productive energy determinations with growing chicks. J. Nutr. 64: 587.

Hogan, J. P., R. H. Weston and J. R. Lindsay. 1969. The digestion of pasture plants by sheep. 4 . The digestion of Phalaris Tuberosa at different stages of maturity. Aust. J. Agric. Res. 20:925.

Johnson, R. R. 1976. Influence of carbohydrate solubility on non-protein nitrogen utilization in the ruminant. J. Anim. Sci. 43:184.

Jouany, J. P. and J. Senaud. 1979. Description d'une technique permettant d'effectuer des prelevements repetes de gaz dans le rumen. Ann. Biol. Anim. Biochim. Biophys. 19:1007.

Krebs, H. A. 1964. The metabolic fate of amino acids. In: H. N. Munro and J. B. Allison (Ed.) Mammalian Protein Metabolism. Pp 125-176. Academic Press, New York.

Martin, L. C., C. B. Ammerman, P. R. Henry and P. E. Loggins. 1981. Effect of level and form of supplemental energy and nitrogen on utilization of low quality roughage by sheep. J. Anim. Sci. 53: 479.

Mills, R. C., L. C. Lardinois, I. W. Rupel and E. B. Hart. 1944. Utilization of urea and growth of heifer calves with corn molasses or cane molasses as the only readily available carbohydrate in the ration. J. Dairy Sci. 27:571.

Mulholland, J. G., J. B. Coombe and W. R. McManus. 1976. Effect of starch on the utilization by sheep of a straw diet supplemented with urea and minerals. Aust. J. Agric. Res. 27:139.

Nolan, J. V., B. W. Norton, R. M. Murray, F. M. Ball, F. B. Roseby, W. Rohan-Jones, M. K. Hill and R. E. Leng. 1975. Body weight and wool production in grazing sheep given access to a supplement of urea and molasses: Intake of supplement/ response relationships. J. Agric. Sci. (Camb.) 86: 39.

NRC. 1985. Nutrient Requirements of Domestic Animals, No. 5. Nutrient Requirements of Sheep. Sixth Revised Ed. National Academy of SciencesNational Research Council, Washington, DC.

Oldham, J. D. and D. B. Lindsay. 1983. Interrelationships between protein yielding and energy yielding nutrients. In: M. Arnal, R. Pion and D. Bonin 
(Ed.) Protein Metabolism and Nutrition. Vol. 1. pp 183-209. Institut National de Recherche Agronomique, Versailles.

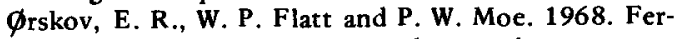
mentation balance approach to estimate extent of fermentation and efficiency of volatile fatty acid formation in ruminants. J. Dairy Sci. 51: 1429.

Ortigues, I., J. P. Fontenot, W. H. McClure and M. Cochran. 1982. Nitrogen supplementation to stocker cattle fed poor quality hay. Anim. Sci. Res. Rep. No. 2, VA Agric. Exp. Sta. pp 195208.

Panditharatne, S., V. G. Allen, J. P. Fontenot and W. H. McClure. 1986. Yield, chemical composition and digestibility by sheep of orchardgrass fertilized with different rates of nitrogen and sulfur or associated red clover. J. Anim. Sci. 62: 813.

Poncet, C. 1976. Utilisation du cerium-141 comme marqueur de la phase solide des contenus digestifs chez les ruminants. Ann. Biol. Anim. Biochim. Biophys. 16:731.

Redman, R. G., R. C. Kellaway and J. Leibholz. 1980. Utilization of low quality roughages: Effects of urea and protein supplements of differing solubility on digesta flows, intake and growth rate of cattle eating oaten chaff. Br. J. Nutr. 44:343.

Schauer, N. L. and J. G. Ferry. 1980. Metabolism of formate in Methanobacterium formicisum. J.
Bacteriol. 142:800.

SAS, 1982. SAS User's Guide: Statistics. SAS Institute, Inc., Cary, NC.

Sumio, Y., M. Okubo, J. Sekine and Y. Asahida. 1983. Collection of rumen gases from young calves. Jpn. J. Zootech. Sci. 54:60.

Thomas, P. C. and J. C. Hodgson. 1979. The clearance rate of rumen liquid and rumen fermentation pattern in sheep receiving forage diets. J. Agric. Sci. (Camb.) 92:683.

Thomas, P. C. and J.A.F. Rook. 1981. Manipulation of rumen fermentation. In: W. Haresign and D.J.A. Cole (Ed.) Recent Developments in Ruminant Nutrition. PP 157-183. Butterworths, London.

Ulyatt, M. J., D. W. Dellow, C.S.W. Reid and T. Bauchop. 1975. Structure and function of the large intestine of ruminants. In: I. W. McDonald and A.C.I. Warner. (Ed.) Digestion and Metabolism in the Ruminant. pp 119-133. Univ. New England Publ. Unit, Armidale, New South Wales, Aust.

Umbreit, W. W., R. H. Harris and J. F. Stauffer. 1957. Manometric Techniques. p 238. Burgess Publ. Co., Minneapolis, $\mathrm{MN}$.

Visek, W. J. 1972. Effects of urea hydrolysis on cell life span and metabolism. Fed. Proc. 31:1178.

Warner, A.C.I. 1981. Rate of passage of digesta through the gut of mammals and birds. Nutr. Abstr. Rev. Ser. B 51:789. 